\title{
Cell wall-lytic activity in Chlorella fusca
}

\author{
Eckhard Loos and Doris Meindl \\ Institut für Botanik der Universität, Universitätsstrasse 31, D-8400 Regensburg, Federal Republic of Germany
}

\begin{abstract}
The soluble fraction of homogenates of synchronous Chlorella fusca was tested for carbohydrate-lyzing activities. With isolated cell walls and $\beta-1,4-$ mannan or carboxymethyl cellulose as substrates, a sharp increase in activity occurred shortly before release of the daughter cells followed by a decline during release. The lytic activities were partially purified by ammonium sulphate precipitation and analyzed by gel filtration on a calibrated column. Apparent molecular weights were 27,000 for cell wall autolysin(s) and $\beta$-1,4-mannanase, 36,000 for carboxymethyl cellulase and $\geqq 70,000$ for another $\beta$-1,4-mannanase. Incubation of isolated cell walls with an enzyme preparation purified by ammonium sulphate precipitation resulted in release of up to $70 \%$ of the cell wall carbohydrate as monosaccharide, predominantly mannose and glucose. The carbohydrate released in vivo into the culture medium shortly before and during liberation of the daughter cells consisted largely of polymeric material with rhamnose, fucose and mannose as main constituents. Upon poisoning the cells with $\mathrm{NaN}_{3}$ or carbonyl cyanide $p$-trifluoromethoxy-phenylhydrazone, however, a monosaccharide fraction consisting of mannose and glucose was predominant in the medium. It is suggested that the major products of cell wall lysis in vivo are monosaccharides which are rapidly taken up and metabolized by the developing daughter cells in an energy-dependent manner.
\end{abstract}

Key words: Cell cycle - Cell wall (lysis) - Chlorella - $\beta$-1,4-Mannanase.

\section{Introduction}

Cell wall-degrading activities have been observed in several green algae (for review see Schlösser
1981). With Chlamydomonas and Volvox the responsible enzymes appear in the medium during release of daughter cells or colonies (Schlösser 1976; Jaenicke and Waffenschmidt 1979, 1981); they have been characterized as proteinases acting on the cell wall glycoprotein(s). In the chlorococcal alga Chlorella, cell wall lysis preceding liberation of autospores has been inferred from electron microscopic studies (Soeder 1965; Wanka 1968; Atkinson et al. 1972). Further, in the culture medium of Chlorella an activity has been found, which is correlated with autospore release and which is able to remove dyed material from a stained cell wall preparation (Touet and Aach 1979); this may also be taken as evidence for cell wall lysis in Chlorella.

In this work a biochemical approach was made to understand the cell wall-lytic process. In contrast to those of Chlamydomonas and Volvox the cell walls of Chlorella consist chiefly of carbohydrate rich in mannose and glucose (Loos and Meindl 1982). In the first section, the appearance of lytic activity in cell homogenates is demonstrated during the cell cycle with isolated cell walls and other polymers as substrates. In the second part, a partial purification of these enzymes is presented, and finally the degradation products of isolated cell walls are characterized and compared with the products which appear in vivo during lysis of the mother cell wall.

\section{Material and methods}

Plant material and homogenization. Chlorella fusca Shihira et Krauss strain 211-8b was obtained from Sammlung für Algenkulturen, Göttingen, FRG. The algae were synchronized by a $14 \mathrm{~h}$ light $(8,000 \mathrm{~lx}) / 10 \mathrm{~h}$ dark regime and diluted to a density of $1.10^{6}$ cells per mtat the beginning of the light phase: Other conditions of culture were as described previously (Loos and Meindl 1982).

To obtain cell homogenates, the algae were centrifuged, resuspended in $0.02 \mathrm{M}$ potassium phosphate buffer $(\mathrm{pH} \mathrm{6.2)}$ at 
a cell density of $2-2.5 \cdot 10^{8} \mathrm{ml}^{-1}$ and passed twice through a French press; in the experiments for enzyme purification the buffer was $0.1 \mathrm{M}$. The homogenate was centrifuged at $12,000 \mathrm{~g}$ for $10 \mathrm{~min}$ and the supernatant again for $90 \mathrm{~min}$ at $48,000 \mathrm{~g}$. The final supernatant is called the soluble fraction.

Purification procedure. The soluble fraction from batches of $1-2.4 \cdot 10^{10}$ cells was freeze-dried, taken up in half the volume of water and subjected to ammonium sulphate fractionation. The precipitates were dissolved in approx. $10 \mathrm{ml} 0.02 \mathrm{M}$ potassium phosphate buffer ( $\mathrm{pH}$ 6.2) and dialyzed against the same buffer. Precipitates forming during dialysis were centrifuged and discarded. The ammonium sulphate fractions were freezedried, taken up in 1-1.5 ml water, centrifuged to remove insoluble material and applied to a Bio-Gel P-100 column (Bio-Rad Laboratories, Munich, FRG; length $103 \mathrm{~cm}$, diameter $1.5 \mathrm{~cm}$ ). The column was eluted with $0.1 \mathrm{M}$ potassium-phosphate buffer ( $\mathrm{pH}$ 6.2) containing $0.02 \% \mathrm{NaN}_{3}$ and fractions of $3 \mathrm{ml}$ were collected. All operations after harvest of the algae were carried out at $0-4^{\circ} \mathrm{C}$.

Substrates. Cell walls were isolated from synchronized algae $16 \mathrm{~h}$ after inoculation as described previously (Loos and Meindl 1982). A D-mannan containing $\beta$-1,4-linkages (Aspinall et al. 1953) was prepared from ivory nut as fraction $\mathrm{IA}_{1}$ according to Meier (1958). A $\beta-1,6$-mannan from a yeast mutant was kindly supplied by Dr. Lehle (Institute of Botany) and laminarin by Dr. Blaschek (Institute of Pharmacy, University of Regensburg, FRG). Xylan and carboxymethyl cellulose were purchased from Sigma Chemie GmbH, München (FRG).

Tests for enzymatic activity. All tests were carried out at $30^{\circ} \mathrm{C}$. With carboxymethyl cellulose and $\beta-1,6$-mannan as substrates the appearance of reducing groups was measured according to Folin (1929) with glucose as reference. With the other substrates, carbohydrate was determined in the supernatant of a centrifuged sample using the phenol-sulphuric acid method (Dubois et al. 1956) with mannose as reference. Since the ivory nut mannan was partially water-soluble the samples were precipitated in this case before centrifugation by adding twice the volume of ethanol and keeping them for $5 \mathrm{~min}$ on ice. The incubation times used were in the range from 10 to $60 \mathrm{~min}$. Protein concentrations were determined after Lowry et al. (1951).

Analysis of products of lysis. For separation, a Bio-Gel P-2 column $(140 \mathrm{~cm}$ length, diameter $1 \mathrm{~cm})$ was used with $0.1 \mathrm{M}$ ammonium acetate buffer (pH 6.8) containing $0.01 \% \mathrm{NaN}_{3}$. Samples of $0.8 \mathrm{ml}$ were applied to the column and fractions of $1.7 \mathrm{ml}$ were collected; aliquots of $0.05-1.0 \mathrm{ml}$ were assayed for carbohydrate content. Hydrolysis of oligo- and polysaccharide fractions was achieved with $2 \mathrm{M}$ trifluoroacetic acid for $2 \mathrm{~h}$ at $100^{\circ} \mathrm{C}$. Neutral sugars were determined by gas liquid chromatography as described previously (Blumreisinger et al. 1983). In addition, qualitative analyses were made using thinlayer chromatography on HPTLC silica gel plates (Merck Darmstadt, FRG) with solvent system 27 of Ghebregzabher et al. (1976); staining was done with a diphenylamine-aniline reagent.

\section{Results and discussion}

Lytic activities in the cell cycle. The soluble fraction of cell homogenates was tested for lytic activity with different substrates at various stages of the cell cycle (Fig. 1). A drastic increase in lysis of iso-

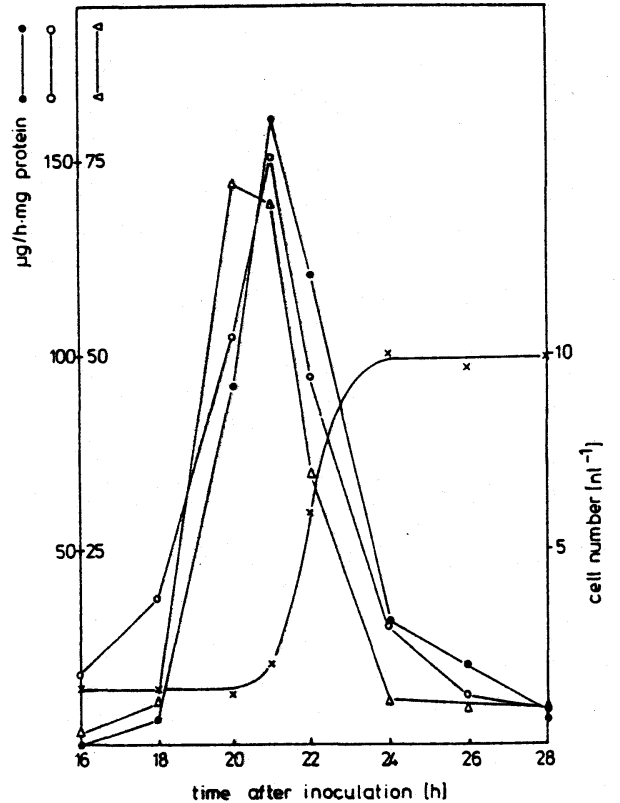

Fig. 1. Lytic activities of the soluble fraction of Chlorella fusca cells homogenized at different times after inoculation. Cell wall lysis (-०); $\beta$-1,4-mannanase (०- $)$; carboxymethyl cellulase $(\Delta-\Delta)$; cell number $(x-\times)$. The incubation mixture contained, in $0.016 \mathrm{M}$ potassium phosphate buffer $(\mathrm{pH} 6.2)$, cell walls or mannan at a concentration of $1.8 \mathrm{mg} \mathrm{ml}^{-1}, 0.02 \%$ $\mathrm{NaN}_{3}$ and $0.83-1.34 \mathrm{mg}$ protein $\mathrm{ml}^{-1}$

lated cell walls, $\beta$-1,4-mannan and carboxymethyl cellulose was seen just prior to the release of the autospores. This indicates that one or more of the responsible enzymes is required for hatching. Negative results were obtained with laminarin, $\beta-1,6-$ mannan, xylan and $\alpha$-cellulose as substrates (data not shown).

Preliminary experiments also showed a severalfold increase in proteinase activity; since, however, the cell wall of $C$. fusca consists largely of carbohydrate (Loos and Meindl 1982), most of the lytic process should be caused by carbohydrases. An eventual role of proteinase(s) for the activation of such carbohydrases or for more complete degradation of the cell wall has still to be shown.

During autospore release a sharp decline of the lytic activities was observed (Fig. 1). This could be a consequence of loss of the enzyme(s) into the medium as soon as the mother cell wall is lysed or opened. In contrast to a previous report (Touet and Aach 1979), however, we were not able to detect cell wall-lytic activity in the medium (data not shown). It is suggested, therefore, that the walldegrading activity is either inactivated or remains bound to the remnants of the old cell wall.

Analogous to Chlorella, a correlation between the appearance of a cell wall-lytic enzyme (an endo-glucanase) and the release of ascospores is 
Table 1. Purification of lytic activities in Chlorella fusca harvested $21 \mathrm{~h}$ after inoculation. The test medium was $0.04 \mathrm{M}$ potassium phosphate buffer ( $\mathrm{pH} 6.2$ ) with $0.02 \% \mathrm{NaN}_{3}$; the substrate concentration was $1.8 \mathrm{mg} \mathrm{ml}^{-1}$ for $\beta$-1,4-mannan and isolated cell walls, $5.0 \mathrm{mg} \mathrm{ml}^{-1}$ for carboxymethyl cellulose. Absolute values of specific activities in the homogenate were comparable to those given in Fig. 1 for the $21 \mathrm{~h}$ stage. The ammonium sulphate fraction of $25-55 \%$ saturation was purified on the Bio-Gel P-100 column

\begin{tabular}{|c|c|c|c|c|c|c|}
\hline & \multicolumn{2}{|c|}{ Cell wall lysis } & \multicolumn{2}{|c|}{$\beta$-1,4-Mannanase } & \multicolumn{2}{|c|}{ Carboxymethyl cellulase } \\
\hline & $\begin{array}{l}\text { Specific } \\
\text { activity } \\
\text { (relative) }\end{array}$ & $\begin{array}{l}\text { Yield } \\
(\%)\end{array}$ & $\begin{array}{l}\text { Specific } \\
\text { activity } \\
\text { (relative) }\end{array}$ & $\begin{array}{l}\text { Yield } \\
(\%)\end{array}$ & $\begin{array}{l}\text { Specific } \\
\text { activity } \\
\text { (relative) }\end{array}$ & $\begin{array}{l}\text { Yield } \\
(\%)\end{array}$ \\
\hline Homogenate (soluble fraction) & 1 & 100 & 1 & 100 & 1 & 100 \\
\hline $\begin{array}{l}\text { Ammonium sulphate fraction } \\
\text { (\% saturation) }\end{array}$ & . & & & & & \\
\hline $\begin{array}{r}0-25 \\
25-55 \\
55-100\end{array}$ & $\begin{array}{l}0 \\
3.0 \\
0\end{array}$ & $\begin{array}{r}0 \\
138 \\
0\end{array}$ & $\begin{array}{l}7.8 \\
1.0 \\
0\end{array}$ & $\begin{array}{c}18.4 \\
47.0 \\
0\end{array}$ & $\begin{array}{l}1.6 \\
1.1 \\
0\end{array}$ & $\begin{array}{r}3.8 \\
50.6 \\
0\end{array}$ \\
\hline Bio-Gel P-100 column & & & & & & \\
\hline $\begin{array}{l}\text { Pools of fractions Nos. } \\
\qquad \begin{array}{l}17,18 \\
23-27 \\
28-33\end{array}\end{array}$ & $\begin{array}{l}- \\
\overline{55.0}\end{array}$ & $\begin{array}{l}- \\
\overline{90.5}\end{array}$ & $\frac{1.8}{27.4}$ & $\begin{array}{l}8.2 \\
45.4\end{array}$ & $\overline{24.8}$ & $\overline{36.7}$ \\
\hline
\end{tabular}

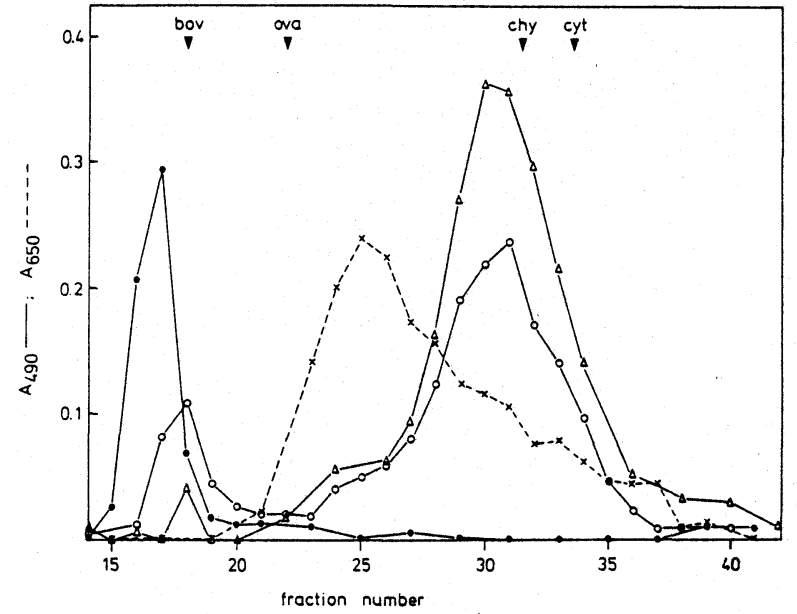

Fig. 2. Gel filtration of lytic activities from the $25-55 \%$ ammonium sulphate fraction of Chlorella fusca cells with the substrates $\beta$-1,4-mannan (०-0), isolated cell walls $(\Delta-\Delta)$ and from the $0-25 \%$ ammonium sulphate fraction with $\beta-1,4$-mannan as substrate $(\bullet-)$ ). At the top are indicated the positions of marker proteins in test runs; $b o v=$ bovine serum albumin, ova $=$ ovalbumin, chy $=$ chymotrypsinogen, $c y t=$ cytochrome $\mathrm{c}$

known for the yeast Schizosaccharomyces pombe (Fleet and Phaff 1981).

Purification of lytic activities. The result of a purification procedure - representative for three preparations - is summarized in Table 1. A conspicous effect achieved in the course-of ammonium sulphate fractionation was the formation of a green precipitate (to be discarded) during dialysis of the fractions. In the $25-55 \%$ ammonium sulphate frac- tion cell wall-lytic activity was enriched and total activity increased. This could be caused by the elimination of the green material which eventually stuck to the cell walls in the assay with the homogenate or by the removal of an inhibitor of enzyme activity. For carboxymethyl cellulase and $\beta-1,4-$ mannanase, most activity was recovered in the fraction which also contained cell wall-lytic activity, but with no enrichment. Considerable further purification was effected by gel filtration (Table 1). A column profile of the different lytic activities from the $25-55 \%$ ammonium sulphate fraction is shown in Fig. 2. Cell wall-lytic activity eluted in a prominent peak corresponding to an apparent molecular weight $\left(\mathrm{M}_{\mathrm{r}}\right)$ of approx. 27,000 ; the slight activity seen in the excluded fractions is considered to be uncertain. $\beta$-1,4-Mannanase activity was separated in two peaks of which one was in the region of large molecular size $M_{r} \geqq 70,000$ ). The other coincided with the cell wall-lytic activity indicating that cell wall lysis may be catalyzed by a $\beta-1,4-$ mannanase. The involvement of a mannanase has to be postulated also because of the high mannose content of the cell wall of C. fusca (Loos and Meindl 1982).

Carboxymethyl cellulase activity appeared in an intermediate position $\left(\mathrm{M}_{\mathrm{r}} 36,000\right)$ and extended far towards the fractions representing smaller molecular-size. This-could-be-eaused-by-an-overlapping of unspecific hydrolytic activity of the $\beta-1,4-$ mannanase in this range. The column profile of the $\beta-1,4-$ mannanase activity from the $0-25 \%$ am- 


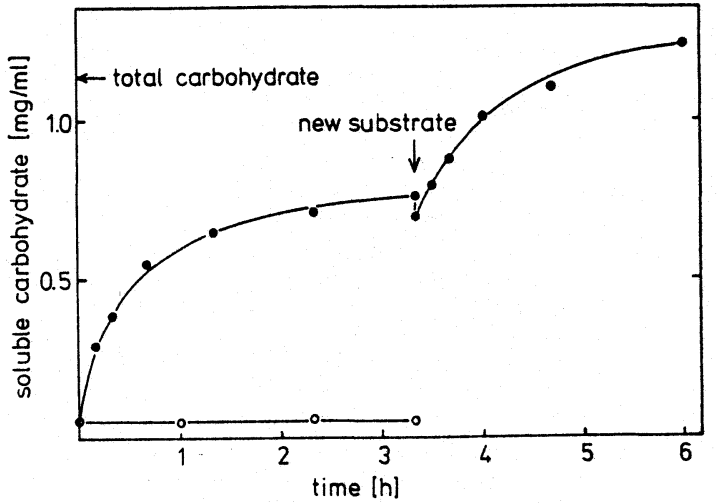

Fig. 3. Kinetics of carbohydrate release from isolated Chlorella

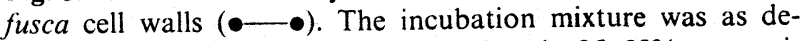
scribed in the legend to Fig. 1 except that the $25-55 \%$ ammonium-sulphate fraction was used at a protein concentration of $2.0 \mathrm{mg} \mathrm{ml}^{-1}$. Total carbohydrate was determined from an aliquot which had not been centrifuged. After $200 \mathrm{~min}, 2 \mathrm{mg}$ of cell walls suspended in $0.2 \mathrm{ml}$ water were added per $\mathrm{ml}$. With the heat-treated sample $(0-0)$ the ammonium sulphate fraction was kept for $5 \mathrm{~min}$ at $100^{\circ} \mathrm{C}$ before use

monium sulphate fraction showed just one maximum appearing in the void volume. This activity may be identical with the corresponding $\beta-1,4-$ mannanase of the $25-55 \%$ ammonium sulphate fraction.

The function of carboxymethyl cellulase (a $\beta$-1,4-glucanase) and the high molecular weight mannanase is not known. Eventually they act in vivo on some component of the cell wall which is missing in the test with isolated cell walls. Alternatively, they may play a role in the synthesis of the walls of the daughter cells. This would be plausible since at about the time when these enzymes are appearing, the new cell walls are being formed (Wanka 1968), and because hydrolases are considered to participate in cell wall growth (Matile 1975).

Kinetics and products of cell wall lysis in vitro. These experiments were carried out with the $25-55 \%$ ammonium sulphate fraction. The kinetics revealed an initial rapid release of carbohydrate and, after about $1.5 \mathrm{~h}$, an approach to saturation (Fig. 3). Obviously, this was caused by depletion of substrate since addition of new cell walls at this stage caused a further increase in soluble carbohydrate. After an incubation period of about $3 \mathrm{~h} 60-70 \%$ of the carbohydrate of the cell wall had been lyzed. Some of the soluble carbohydrate was introduced with the crude enzyme-preparation; this is-seen in Fig. 3 in the value for time zero which had been determined before addition of the cell walls. A control with a heat-treated enzyme preparation showed no activity at all.

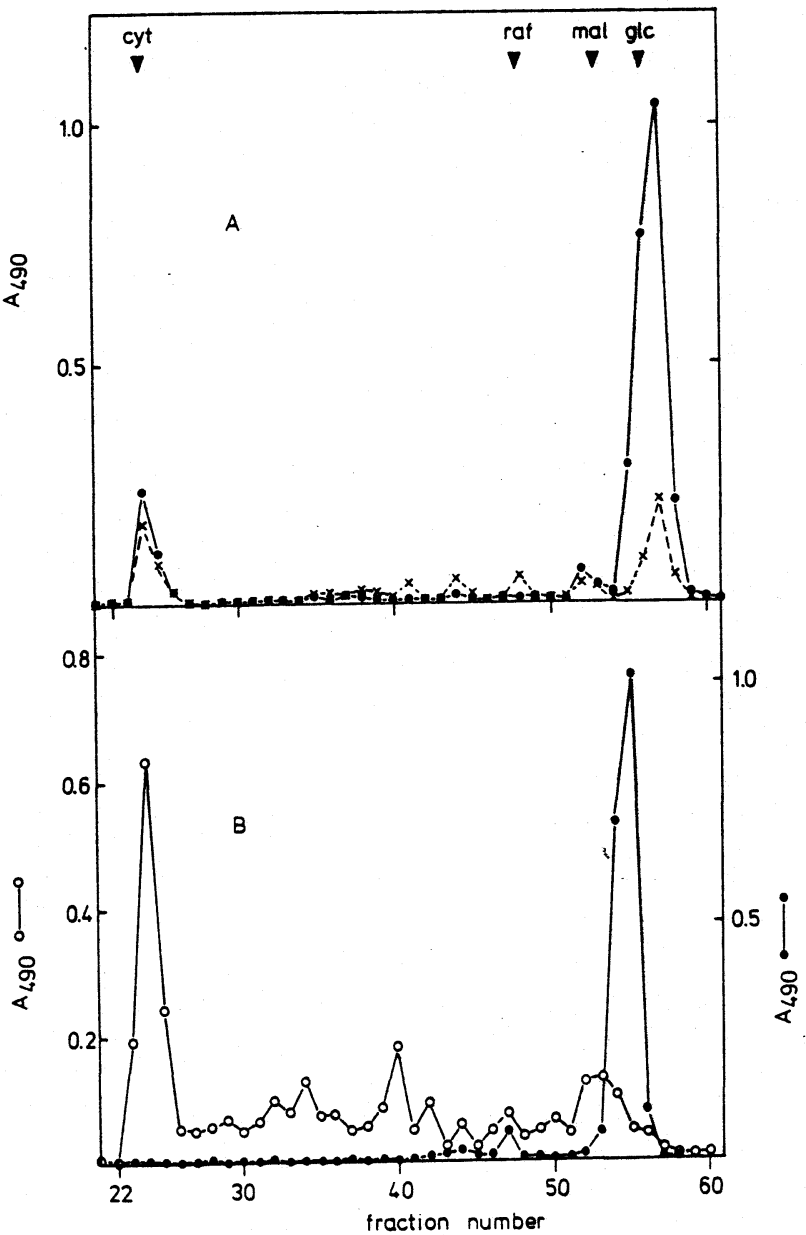

Fig. 4. A Elution profile of carbohydrate released from Chlorella cell walls after $200 \mathrm{~min}(\bullet-\bullet)$ and $10 \mathrm{~min}(\mathrm{x}-\mathrm{x})$ incubation time; separation by gel filtration. The incubation mixture was as described in the legend to Fig. 1, except that the $25-55 \%$ ammonium sulphate fraction was used at a protein concentration of $2.0 \mathrm{mg} \mathrm{ml}^{-1}$. After centrifugation, $4.5 \mathrm{ml}$ of the supernatant were kept for $5 \mathrm{~min}$ at $100^{\circ} \mathrm{C}$ to stop enzymatic activity and were freeze-dried before application to the column. At the top are indicated the positions of marker substances in a test run; $c y t=$ cytochrome c, $r a f=$ raffinose, $m a l=$ maltose, $g l c=$ glucose. B Elution profile of carbohydrate excreted by Chlorella between 18.5 and $23.5 \mathrm{~h}$ after inoculation in the absence $(0-0)$ and presence $(\bullet-)$ ) of $6 \cdot 10^{-3} \mathrm{M} \mathrm{NaN}_{3}$. The algae were contained in fresh medium at a density of $3.0 \cdot 10^{7}$ cells $\mathrm{ml}^{-1}$, bubbled with $2 \% \mathrm{CO}_{2}$ in air and centrifuged at the end of the incubation; $100 \mathrm{ml}$ of the supernatant were kept for 5 min at $100^{\circ} \mathrm{C}$ to stop an eventual enzymatic activity in the medium, freeze-dried and applied to the column after removal of insoluble material (e.g. phosphates) by centrifugation. From each fraction, 0.1 and $1.0 \mathrm{ml}$ aliquots with and without $\mathrm{NaN}_{3}$, respectively, were assayed for carbohydrate

The products of cell wall lysis were separated by get-filtration (Fig. 4A). After-prolonged-incubation $(200 \mathrm{~min})$, a large monosaccharide fraction was observed consisting of $61-70 \%$ mannose, $28-30 \%$ glucose and $\leqq 2.5 \%$ unknown sugars (three experiments). The smaller polymeric frac- 
tion $\left(M_{r} \geqq 2,000\right)$ seemed to originate from the crude enzyme preparation since upon hydrolysis of this fraction and of the enzyme preparation a similar pattern of neutral sugars was obtained, with an unknown component migrating between fucose and arabinose in gas liquid chromatography.

After a short period of incubation $(10 \mathrm{~min})$, besides the monosaccharide fraction smaller peaks were encountered corresponding to oligosaccharides. This indicates for the lytic process to be responsible both, endo- and exoenzyme activities.

Analysis of products excreted in the course of autospore release. To test whether the products of cell wall lysis in vitro were similar to those occurring in vivo, analyses were made of the culture medium assuming that cell wall degradation products should appear there. For this purpose, the algae were harvested at the onset of lytic activity (18 h after inoculation, compare Fig. 1), washed and incubated in fresh medium. After sporulation had occurred, the medium was analyzed by gel filtration. The most prominent fraction was of large molecular size $\left(M_{r} \geqq 2,000\right.$, Fig. 4B). After hydrolysis, rhamnose, fucose and mannose were identified as its main constituents. They varied somewhat in their proportions from one experiment to the other; together they accounted for $80 \%$ of the total sugars in the hydrolysate. The relatively small monosaccharide fraction contained, besides a trace of glucose, only rhamnose. Because of its high rhamnose content it appeared slightly before the position of glucose; this was concluded from test runs showing rhamnose to elute in a smaller volume than glucose.

To see whether the carbohydrate released into the medium could originate in its quantity from the cell wall, a comparison was made with the total carbohydrate content of the cell walls. The latter was known from previous cell wall analyses (Loos and Meindl 1982). The carbohydrate in the medium was estimated to be equivalent to $5-10 \%$ of that in the cell wall.

These results show that the products released shortly before and during liberation of autospores are different from those of the in vitro experiments with respect to molecular size distribution, the pattern of sugars and their quantity in relation to the cell wall. To explain these discrepancies, it was supposed that in vivo the cell wall degradation products, mannose and glucose, are taken up rapidly by the newly forming autospores and thus are not appearing in the medium. If this uptake process and/or further metabolism of these monosacchar- ides is blocked by some poison, and if the action of the lytic enzyme(s) is not, one would expect mannose and glucose to accumulate in the culture medium.

When the algae were incubated as above, but in the presence of $\mathrm{NaN}_{3}$, the release of daughter cells was completely inhibited; the respiration, as measured by the direct method of Warburg, was $15 \%$ of the control. The amount of carbohydrate appearing in the medium increased two- to fourfold and the elution profile of the gel filtration had changed drastically: almost all of the carbohydrate was monomeric; it consisted of $91.8-99.3 \%$ mannose, $0.7-7 \%$ glucose and $0-1.2 \%$ xylose (data from two experiments). In an experiment in which $10^{-4} \mathrm{M}$ carbonyl cyanide $p$-trifluoro-methoxyphenylhydrazone was used instead of $\mathrm{NaN}_{3}$, the monosaccharide fraction also comprised most of the total carbohydrate $(63 \%)$ and contained $50.1 \%$ mannose, $37.7 \%$ glucose and $12.2 \%$ other sugars.

A point which is not yet understood is the disappearance of the fraction of large molecular size upon poisoning the cells with $\mathrm{NaN}_{3}$. Otherwise, the results agree with the idea that in vivo also the main products of cell wall lysis are monosaccharides which are taken up effectively by the developing daughter cells. This view is favored since the strain of Chlorella used here has been shown to take up externally supplied mannose and glucose (Hülsen and Prenzel 1967). A reuse of material of the mother cell wall has also been suggested since the disappearance of the bulk of the old cell wall is closely related to the formation of the new walls (electron-microscopic studies: Wanka 1968; Atkinson et al. 1972).

Thanks are due to Dr. A. Haselbeck and Dr. W. Lockau for discussions. Financial support was obtained from the Deutsche Forschungsgemeinschaft.

\section{References}

Aspinall, G.O., Hirst, E.L., Percival, E.G.V., Williamson, J.R (1953) The mannans of ivory nut (Phytelephas macrocarpa) I. The methylation of mannan A and mannan B. J. Chem. Soc. (London) Part III. 3184-3188

Atkinson, Jr. A.W., Gunning, B.E.S., John, P.C.L. (1972) Sporopollenin in the cell wall of Chlorella and other algae: Ultrastructure, chemistry, and incorporation of ${ }^{14} \mathrm{C}$-acetate, studied in synchronous cultures. Planta 107, 1-32

Blumreisinger, M., Meindl, D., Loos, E. (1983) Cell wall composition of chlorococcal algae. Phytochemistry 22, 1603-1604

Dubois, M., Gilles, K.A., Hamilton, J.K., Rebers, P.A., Smith, F. (1956) Colorimetric method for determination of sugars and related substances. Anal. Chem. 28, 350-356

Fleet, Y.H., Phaff, H.J. (1981) Fungal glucans-structure and metabolism. In: Encyclopedia of plant physiology, N.S., vol. 13 B: Plant carbohydrates II, pp. 416-440, Tanner, 
W., Loewus, F.A., eds. Springer, Berlin Heidelberg New York

Folin, O. (1929) Two revised copper methods for blood sugar determination. J. Biol. Chem. 82, 83-93

Ghebregzabher, M., Rufini, S., Monaldi, B., Lato, M. (1976) Thin-layer chromatography of carbohydrates. J. Chromatogr. 127, 133-162

Hülsen, W., Prenzel, U. (1967) Über die Konzentrationsabhängigkeit der Aufnahme verschiedener Zucker durch Chlorella pyrenoidosa. Z. Naturforsch. Teil B 22, 683-684

Jaenicke, L., Waffenschmidt, S. (1979) Matrix-lysis and release of daughter spheroids in Volvox carteri - a proteolytic process. FEBS Lett. 107, 250-253

Jaenicke, L., Waffenschmidt, S. (1981) Liberation of reproductive units in Volvox and Chlamydomonas: proteolytic processes. Ber. Dtsch. Bot. Ges. 94, 375-386

Loos, E., Meindl, D. (1982) Cell wall composition of Chlorella fusca. Planta 156, 270-273

Lowry, O.H., Rosebrough, N.J., Farr, A.L., Randall, R.J. (1951) Protein measurement with the folin phenol reagent. J. Biol. Chem. 193, 265-275

Matile, Ph. (1975) The lytic compartment of plant cells. Springer, Wien New York (Cell biology monographs, vol. 1)
Meier, H. (1958) On the structure of cell walls and cell wall mannans from ivory nuts and from dates. Biochim. Biophys. Acta 28, 229-240

Schlösser, U.G. (1976) Entwicklungsstadien - und sippenspezifische Zellwand-Autolysine bei der Freisetzung von Fortpflanzungszellen in der Gattung Chlamydomonas. Ber. Dtsch. Bot. Ges. 89, 1-56

Schlösser, R.G. (1981) Algal wall-degrading enzymes - autolysines. In: Encyclopedia of plant physiology, N.S., vol. 13 B: Plant carbohydrates II, pp. 333-352, Tanner, W., Loewus, F.A., eds. Springer, Berlin Heidelberg New York

Soeder, C.J. (1965) Elektronenmikroskopische Untersuchungen der Protoplastenteilung bei Chlorella fusca Shihira et Krauss. Arch. Mikrobiol. 50, 368-377

Touet, G., Aach, H.G. (1979) Isolation and first characterization of a cell-wall-degrading agent of Chlorella. Naturwissenschaften 66, 525

Wanka, F. (1968) Ultrastructural changes during normal and colchicine - inhibited cell division of Chlorella. Protoplasma 66, 105-130

Received 27 July; accepted 10 October 1983 